\title{
Strengthening of R.C Short Column with Partial Replacement of Bacillus Bacteriain Cement
}

\author{
K. VijayaSundravel ${ }^{1, *}$, S.Ramesh ${ }^{2}$, D.Jegatheeswaran ${ }^{3}$ \\ ${ }^{I}$ AssistantProfessor, Department of Civil Engineering, K.S.Rangasamy College of Technology, Tamil Nadu, India. \\ ${ }^{2}$ Professor, Department of Civil Engineering, K.S.Rangasamy College of Technology, Tamil Nadu, India. \\ Professor, Department of Civil Engineering, Sona College of Technology, Tamil Nadu, India \\ *Corresponding author E-Mail ID: vijayaksr@hmail.com
}

Doi: https://doi.org/10.34256/irjmtcon48

\begin{abstract}
In this paper the strength behavior of Bacillus Bacteria and strengthening characteristic of GFRP sheets are investigated. In this study the optimum percentage of Bacillus Bacteria is find out from the compressive strength test. The cubes are casted based on the percentage replacement of Bacillus Bacteria in cement. The replacement of Bacillus Bacteria in cement is $0 \%, 10 \%, 20 \%$, $30 \% 40 \%, 50 \%$. Totally 18 cubes are casted out of this 3 cubes for each percentage. After 28 days the compressive strength was find out from the cubes. From the compressive strength test the optimum percentage of Bacillus Bacteria is concluded as $20 \%$. Based on these result columns are casted. Totally 12 columns are casted out of these columns 6 columns are conventional and 6 columns are Bacillus Bacteria replace columns. The axial compressive strength test was carried on 3 conventional and 3 Bacillus Bacteria replaced column to find out the ultimate load carrying capacity. From this ultimate load $70 \%$ of load is given to the remaining columns as a preloading. After given the preloading these columns are strengthened by using GFRP sheets. The strengthened columns are tested under axial compression test. From this result the ultimate load carrying capacity, deflection, stiffness, and energy absorption of column is calculated.
\end{abstract}

Keywords: Bacillus Bacteria, GFRP sheets.

\section{INTRODUCTION}

\section{A. Bacillus Bacteria}

Bacillus, (genus Bacillus), any of a cluster of rod-shaped, gram-positive, aerobic or (underneath some situations) anaerobic bacteria broadly found in soil and water. The term bacillus has been useful in a general sense to all tubular or pole like bacteria. The prime known Bacillus species, B. moratorium, is about $1.5 \mu \mathrm{m}$ (micrometres; $1 \mu \mathrm{m}=10-6 \mathrm{~m}$ ) across by $4 \mu \mathrm{m}$ long. Bacillus regularly occurs in shackles.

In 1877 German botanist Ferdinand Cohn provided an imposing an explanation of two dissimilar forms of hay bacillus (now known as Bacillus subtilis): one that could be slain upon revelation to warmness and one that was resistant to heat. He called the heat-resistant forms "spores" (endospores) and naked that these dormant forms could be converted to a vegetative, or actively growing, state. Today it is known that all Bacillus species can form resting spores under adverse conservational conditions. These endospores may continue an feasible for long periods of time. End spores are hardly resistant to heat, chemicals, and sunlight and are generally 
disseminated in nature, mostly in soil, from which they invade sand particles. Some kinds of Bacillus bacteria are injurious to humans, plants, or other creatures. For illustration, B. cereus occasionally causes decomposition in canned foods and food poisoning of short duration. B. subtitles is a common pollutant of research laboratory cultures (it plagued Louis Pasteur in many of his experiments) and is frequently found on human skin. Most strains of Bacillus are not pathogenic for humans but May, as soil creatures, taint humans parenthetically. A noteworthy exception is B. anthracis, which causes anthrax in humans and domestic animals. B. thuringiensis produces a toxin (Bt toxin) that causes disease in insects. This in turn reduces the cracks in the structures

\section{B. Glass fibber reinforced polymer (GFRP) sheets}

Glass fiber is called fiber glass. It is material made from extremely fine fiber of glass fibreglass is light weight, extremely strong, and robust material. The glass fiber reinforced polymer is classified into three types. They are

- Chopped Strands Mat (CSM)

- Uni-Directional Cloth (UDC)

- Woven Roving (WR)

Continuous fiber reinforced materials with polymeric matrix (FRP) can be considered as composite, heterogeneous, and anisotropic materials with a prevalent linear elastic behavior up to failure. Normally, Glass and Carbon fibers are used as reinforcing material for FRP. Epoxy is used as the binding material between fiber layers. For this study, GFRP sheet was used during the tests i.e., a bidirectional FRP with the fibre oriented in both longitudinal and transverse directions, due to the flexible nature and ease of handling and application, the FRP sheets are used for shear strengthening. Throughout this study, E-glass was used.

The FRP strips are applied at the bottom (tension) faces for strengthening the slab. The strengthening result in better flexural performance, until the tensile resistance of the slabs is taken by the tensile strength of FRP. The effectiveness of FRP strengthening mainly depends on the performance of the resin chosen for bonding. The side bonding or U-wraps is used for shear strengthening of member. The columns are wrapped with FRP around their perimeter, as with closed or complete wrapping. This strengthening results in higher shear resistance and it results in increased compressive strength under axial loading. The polymerization or addition polymerization is generally used to generate the polymers. The process of alter the material properties or combined with various agents of polymers the result is referred to as a plastic. The composite plastics used the fiber materials to enhance the strength and elasticity of plastics and the fibre-reinforced plastics are under this category. The matrix referred to as original plastic material without fiber reinforcement. They are tough but relatively weak plastic that is enhanced by stronger stiffer reinforcing filaments. The fiber-reinforced plastic strength and elasticity depends on the properties are the matrix, their volume relative to one another, fiber, fiber length and orientation within the matrix. A laminated structure is used to characterise the two dimensional fibre-reinforced polymers by in which the fibres are only aligned along the plane in $\mathrm{y}$-direction and $\mathrm{x}$-direction of the material. This means in z-direction that no fibres are aligned in the through thickness, this lack of alignment on through thickness can cause a disadvantage in processing and cost. The conventional processing techniques used to fabricate composites cause the costs and labour increase, such as, autoclave and resin transfer moulding, wet hand lay-up, require a high amount of skilled labour to stack, cut and consolidate into a preformed component. The three dimensional fibre structures incorporate fibres in the $\mathrm{x}$-direction, $\mathrm{y}$-direction and $\mathrm{z}$ direction. The manufacturing of three-dimensional orientations from industry's need to reduce fabrication costs, to improve impact damage tolerance and to increase through-thickness 
mechanical properties, all were problems associated with two dimensional fibre-reinforced polymers.

Depending on the degree of strengthening and exposed faces of the member FRP can be applied in several configurations, this includes: U-wraps (U-jackets), and side bonding, closed wraps (complete wraps). Side bonding involves FRP applying to the sides of the beam only. The least amount of shear strengthening due to failures caused by de-bonding from the concrete surface at the FRP free edges. The FRP is applied continuously in a ' $U$ ' shape around the sides and bottom (tension) face of the beam in the $U$ wrap. The use of closed wraps is desirable as they provide the most strength enhancement if all faces of a beam are accessible. Closed wrapping involves FRP applying around the entire perimeter of the member, such that there are no typical failure mode is rupture of the fibres and free ends. The FRP can be applied along the length of the member as a discrete strips or continuous sheet as, having a minimum spacing and width for all wrap configurations. From the literature study the points taken as,

1. The workability of concrete increases due to replacement of BACILLUS Bacteria with cement.

2. The setting time of concrete is increased.

3. The corrosion resistance property of concrete is increased.

4. From the above experimental results, it is proved that GGBS can be used as an alternative material for cement, reducing cement consumption and reducing the cost of construction.

5. Use of industrial waste products saves the environment and conserves natural resources.

\section{METHODOLOGY OF STUDY}

The methodology of the project work is shown in fig.1. This is discussed below.

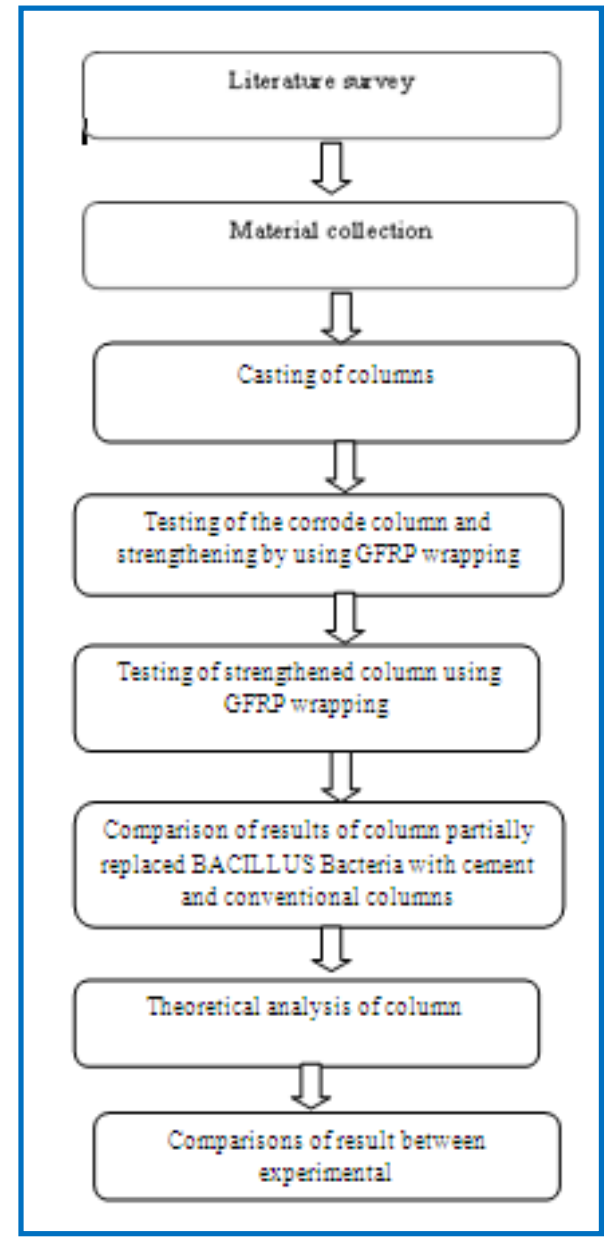

Fig.2.1 Methodology for the project 
K. VijayaSundravel et al. / International Research Journal of Multidisciplinary Technovation /2019, 1(6), 362-372

\section{MATERIAL SPECIFICATION}

The materials used to cast the specimen are described in the chapter. The material to be collected is cement, fine aggregate, coarse aggregate, steel reinforcement, BACILLUS BACTERIA and GFRP sheets.

\section{A. Concrete}

Design concrete mix is to be used for casting the specimen. $\mathrm{M}_{20}$ grade concrete is selected for the column specimen with characteristics compressive strength of $20 \mathrm{~N} / \mathrm{mm}^{2}$. The designed mix proportion is 1:1.5:3. The material for making concrete are selected as follows.

\section{B. Cement}

Ordinary Portland cement 53 grade with specific gravity of 3.15 is to be used.

\section{Fine Aggregate}

The fine aggregate was passing through $4.75 \mathrm{~mm}$ sieve and had a specific gravity of 2.65 . The grading zone of fine aggregate was zone II as per Indian standards specification (IS 383).

\section{Coarse Aggregate}

The maximum size of coarse aggregate used for his investigation is $20 \mathrm{~mm}$ and the specific gravity is 2.7 .

\section{E. Water}

Water should be potable and free from acids, oils, alkalies and other organic impurities.

\section{F. Reinforcement}

HYSD bars of $12 \mathrm{~mm}$ diameter are used as longitudinal bars for column. The lateral ties are to be of $8 \mathrm{~mm}$ diameter.

\section{G. Bacillus Bacteria}

The BACILLUS BACTERIA used to make specimen should be passed through $1 \mathrm{ml}$. The specific gravity of BACILLUS Bacteria is 3.12.

\section{H. Properties of Bacillus Bacteria and Cement}

\section{Chemical composition}

BACILLUS Bacteria comprises mainly of $\mathrm{CaO}, \mathrm{SiO}_{2}, \mathrm{AL}_{2} \mathrm{O}_{3}, \mathrm{MgO}$, it contains less than $1 \%$ crystalline silica, and contain less than $1 \mathrm{ppm}$ water soluble chromium $1 \mathrm{~V}$. It has the same main chemical constituents as ordinary Portland cement, but in different proportion. The chemical composition of BACILLUS Bacteria is shown in table 3.1.

\begin{tabular}{|c|c|c|}
\hline \multicolumn{2}{|c|}{ Table 3.1 Chemical Compositions of Bacillus Bacteria and Cement } \\
\hline $\begin{array}{c}\text { Chemical } \\
\text { composition }\end{array}$ & $\begin{array}{c}\text { Portland } \\
\text { cement }\end{array}$ & $\begin{array}{c}\text { BACILLUS } \\
\text { Bacteria }\end{array}$ \\
\hline $\mathrm{CaO}$ & $65 \%$ & $40 \%$ \\
\hline $\mathrm{SiO}_{2}$ & $20 \%$ & $35 \%$ \\
\hline $\mathrm{AL}_{2} \mathrm{O}_{3}$ & $5 \%$ & $10 \%$ \\
\hline $\mathrm{MgO}$ & $2 \%$ & $8 \%$ \\
\hline
\end{tabular}

Because of the chemical similarities the BACILLUS Bacteria can be replaced for Portland cement mixes by as much as up to $95 \%$. 
K. VijayaSundravel et al. / International Research Journal of Multidisciplinary Technovation /2019, 1(6), 362-372

\section{Physical properties}

The physical properties of BACILLUS Bacteria are shown in the table 3.2.

Table 3.2 Physical Properties of Bacillus

Bacteria

\begin{tabular}{|c|c|}
\hline $\begin{array}{c}\text { Physical } \\
\text { properties }\end{array}$ & $\begin{array}{c}\text { BACILLUS } \\
\text { Bacteria }\end{array}$ \\
\hline Colour & Off white powder \\
\hline $\begin{array}{c}\text { Bulk } \\
\text { density(loose) }\end{array}$ & $1.0-1.1$ tonnes $/ \mathrm{m}^{3}$ \\
\hline $\begin{array}{c}\text { Bulk } \\
\text { density(vibrate) }\end{array}$ & $1.2-1.3$ tonnes $/ \mathrm{m}^{3}$ \\
\hline Surface area & $400-600 \mathrm{~m}^{2} / \mathrm{kg}^{3}$ \\
\hline Specific gravity & 3.15 \\
\hline Soundness & 3.5 \\
\hline $\begin{array}{c}\text { Initial setting } \\
\text { time }\end{array}$ & $150 \mathrm{~min}$ \\
\hline
\end{tabular}

\section{J. GFRP Sheets}

In the project Chopped Strands Mats (CSM) are used for the strengthening process.

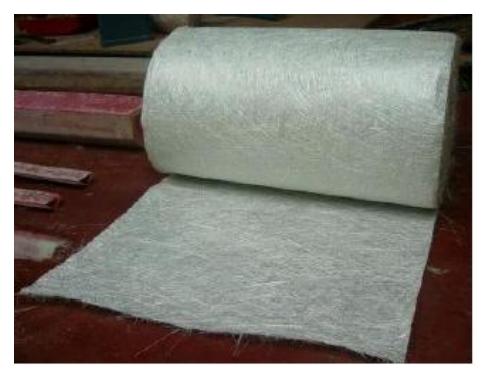

Fig 3.1 GFRP sheet

\section{K. Epoxy Resin}

In this project the GP resin is used to make the binding between the column and GFRP sheets. Before making binding the resin is mixed with the Accelerator and the catalyst. The strengthening behaviour is mainly depends on the resin binding capacity.

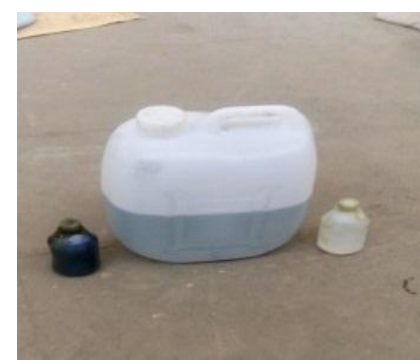

Fig.3.2 GP resin 
Table 3.3. properties of GP resin

\begin{tabular}{|c|c|c|}
\hline Type of concrete & Crushing load $(\mathrm{kg})$ & $\begin{array}{c}\text { Compressive strength } \\
\mathrm{N} / \mathrm{mm} 2\end{array}$ \\
\hline Control concrete & 954 & 28.27 \\
\hline $\begin{array}{c}10 \% \text { BACILLUS } \\
\text { Bacteria }\end{array}$ & 982 & 29.11 \\
\hline $\begin{array}{c}20 \% \text { BACILLUS } \\
\text { Bacteria }\end{array}$ & 1099.9 & 32.59 \\
\hline $\begin{array}{c}30 \% \text { BACILLUS } \\
\text { Bacteria }\end{array}$ & 1042.8 & 30.90 \\
\hline $\begin{array}{c}40 \% \text { BACILLUS } \\
\text { Bacteria }\end{array}$ & 1019.25 & 29.0 \\
\hline $\begin{array}{c}\text { 50\% BACILLUS } \\
\text { Bacteria }\end{array}$ & 936.2 & 30.20 \\
\hline
\end{tabular}

\section{IV.COMPRESSIVE STRENGTH RESULTS}

The cubes are casted to find out the optimum percentage of BACILLUS Bacteria. Totally 18 cubes are casted. The BACILLUS Bacteria replaced with cement is $0 \%, 10 \%, 20 \%, 30 \%, 40 \%$, $50 \%$. The 3 cubes are casted for each percentage of replacement. The mean value is find out from the 3 cubes for each percentage of replacements. The mean compressive strength is shown in the table 3 .

Table 3.4. Compressive Strength of Bacillus Bacteria

\begin{tabular}{|c|c|c|}
\hline Property & Units & Standard value \\
\hline Apperance & & Light yellow/ clear \\
\hline Viscosity @ $30^{\circ} \mathrm{c}$ & Ford cub ‘b4' inseconds & $45-70$ \\
\hline Acid value & $\mathrm{Mg} \mathrm{KOH} / \mathrm{g}$ & $<28$ \\
\hline Volatile contant & $\%$ & $33-38$ \\
\hline Specific gravity & & $1.08-1.15$ \\
\hline
\end{tabular}

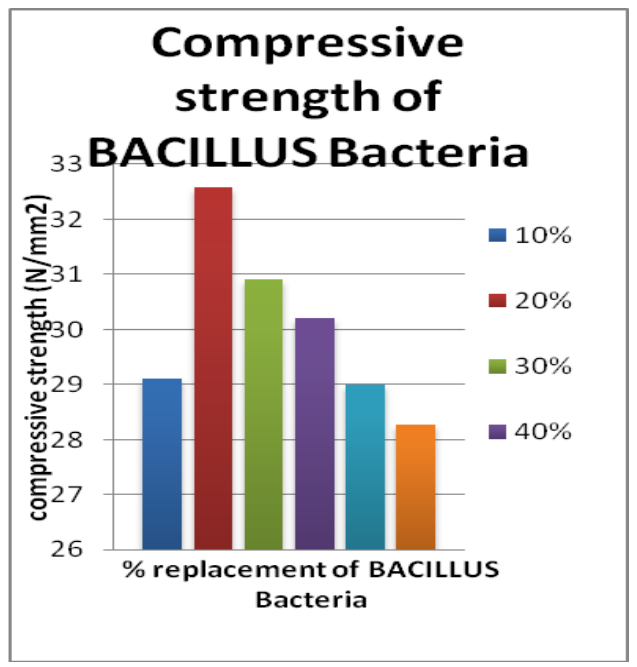

Fig 3.5. Bar diagram for compressive strength of BACILLUS Bacteria 
From the compressive strength result the optimum percentage of BACILLUS Bacteria replaced with cement is found out as $20 \%$. Based on this result the columns are casted.

\section{SPECIMEN DETAILS}

Totally 12 columns to be casted in which 6 is control column. And another 6 column BACILLUS Bacteria partially replaced in place of cement. These columns to be designed as short columns. A square cross section is adopted for the column with a cross sectional dimension of $100 \mathrm{~mm} \times 100 \mathrm{~mm}$. the length of the column is $600 \mathrm{~mm}$. All the columns to be tested under axial compression test. The maximum diameter of longitudinal bar the column is taken as $12 \mathrm{~mm}$ diameter and $8 \mathrm{~mm}$ ties are used.

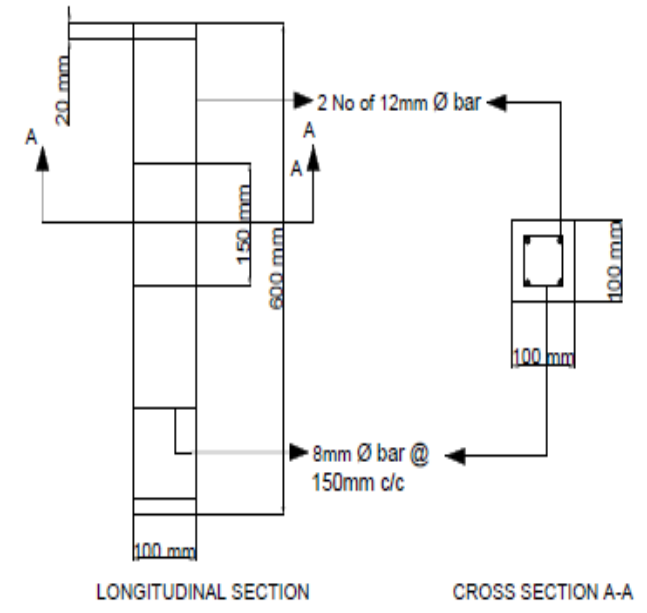

Fig.5.1. Longitudinal and cross section detailing of compressive member

\section{A. Experimental Test Setup for Specimens}

A total of 12 columns were casted. Out of 12 Columns the six columns are casted as a conventional column and six were casted based on optimum percentage of BACILLUS Bacteria. All the columns are tested for compression in universal testing machine of capacity $1000 \mathrm{KN}$. The 2 LVDT is used during testing process. The LVDT's are used to find out the lateral deflection and the buckling of the columns. The loads are gradually increased up to the ultimate load carrying capacity of the column. The load vs deflection curve is shown in the curve 5. and 5.2.

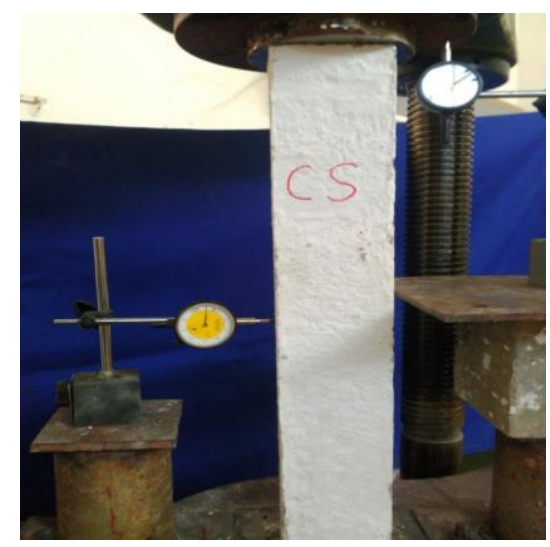

Fig 5.2. Testing of conventional R.C column 


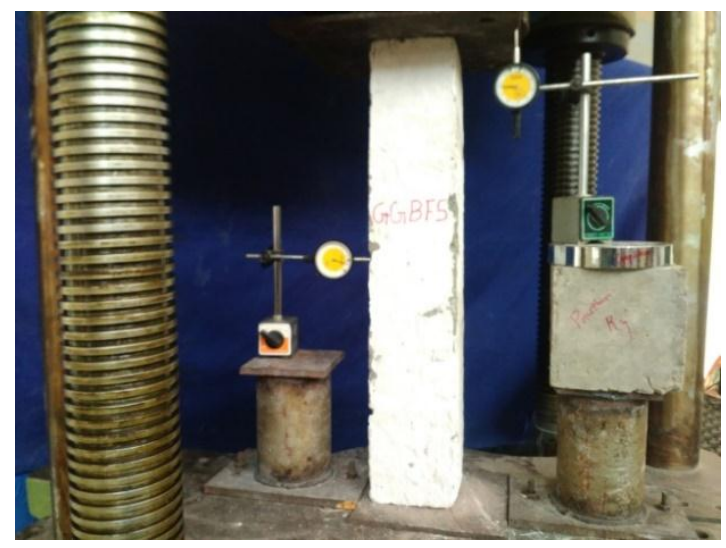

Fig 5.3 Testing of Bacillus Bacteria Replaced R.C Column

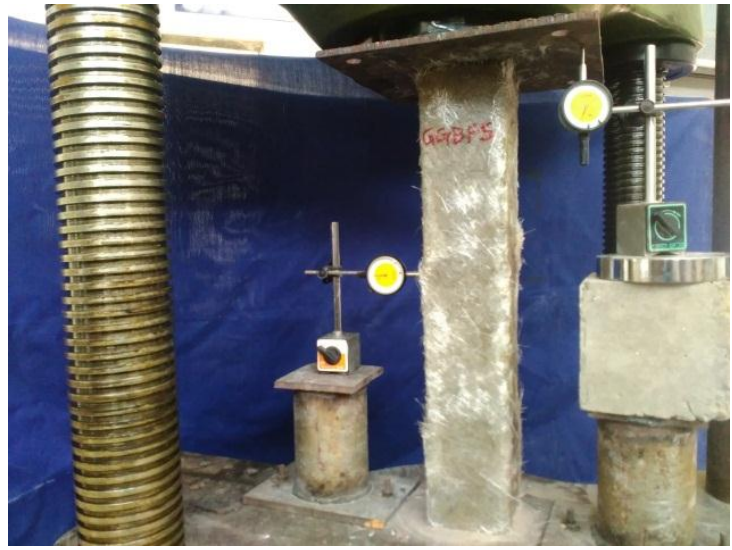

Fig 5.4 Testing of Gfrp Wrapped Bacillus Bacteria Column

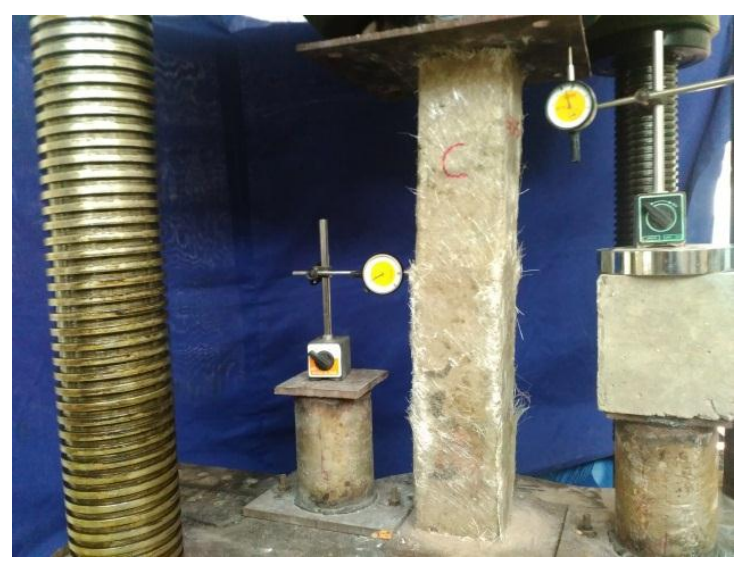

Fig 5.5. Testing of GFRP wrapped conventional column

The 3 conventional and BACILLUS Bacteria replaced columns are tested up to ultimate load. The preloading is given to another 3 conventional and BACILLUS Bacteria replaced columns. After given preloading they are strengthened by using GFRP sheets. The strengthening characteristics of the GFRP sheets are found out from the columns. The graph 5.1 shows the ultimate load carrying capacity of the conventional and BACILLUS Bacteria replaced columns.

The BACILLUS Bacteria replaced column gives the strength more than the conventional column. The BACILLUS Bacteria replace column gives load carrying capacity more than the conventional column and also the deflection is reduced than the conventional column. 


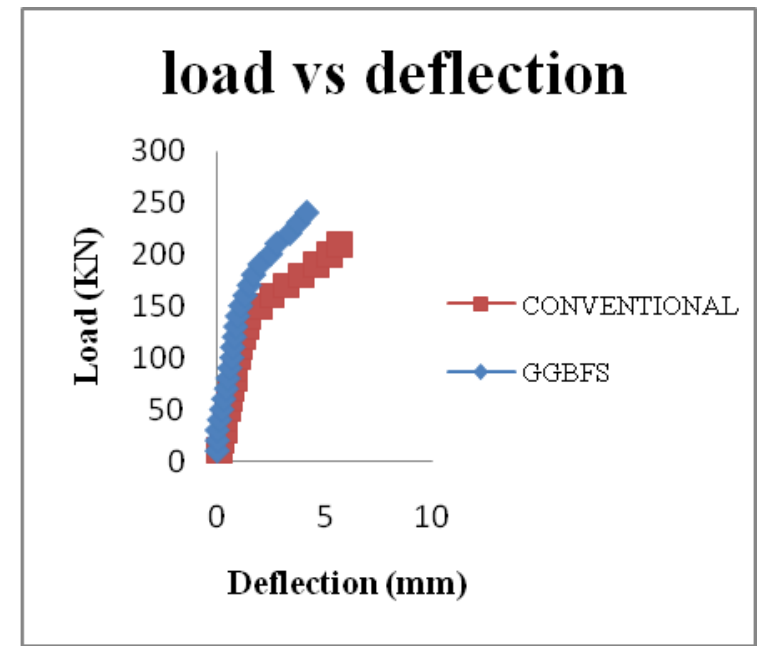

Fig.5.6. Ultimate load vs. deflection for conventional and BACILLUS Bacteria replaced columns.

Another 3 conventional and BACILLUS Bacteria replaced columns are given to a preloading ( $70 \%$ of ultimate load). After given preloading they are strengthened by using GFRP wrapping. The wrapped columns are tested under axial compression test. The load carrying capacity and the deflection are found out from this test.

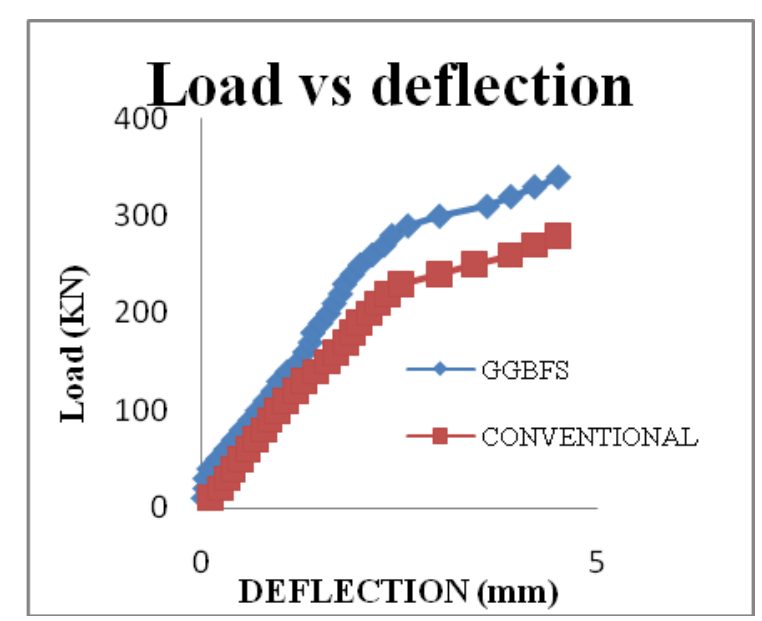

Fig. 5.7. Ultimate load vs. deflection for strengthened conventional and BACILLUS Bacteria replaced columns.

The graph shows the ultimate load carrying capacity is more than the conventional column. From these results concluded the BACILLUS Bacteria replaced column gives the better results than conventional column.

\section{CONCLUSION}

From the experimental result the following points are concluded,

1. The cubes testing results shows the optimum percentage of BACILLUS Bacteria with cement is $20 \%$.

2. The replacement of BACILLUS Bacteria with cement reduces the cost of concrete. The economy concrete will be produced due to replacement of BACILLUS Bacteria with cement. 
K. VijayaSundravel et al. / International Research Journal of Multidisciplinary Technovation /2019, 1(6), 362-372

3. The compressive strength of conventional concrete is $28.27 \mathrm{~N} / \mathrm{mm}^{2}$. The compressive strength of conventional concrete is $32.59 \mathrm{~N} / \mathrm{mm}^{2}$.

4. The columns were casted based on the optimum percentage of BACILLUS Bacteria.

5. The axial compression test is conducted on the all columns to find out the ultimate load carrying capacity of column.

6. The LVDT is used to find the lateral deflection of the columns. Based on these values the load deflection curve is plotted.

7. The BACILLUS Bacteria replaced column load deflection curve shows the ultimate load carrying capacity is high and the deflection is lower than the conventional column.

\section{REFERENCE}

1. Alsayed S.H., Almusallam T.H., S. Ibrahim M., N. Al-Hazmi M., Y.A. Al-Salloum, H. Abbas (2014), "Experimental and Numerical Investigation for Compression Response of CFRP Strengthened Shape Modified Wall-Like RC Column" Journal of Construction and Building Materials, Vol.63, pp.72-80.

2. ArivalaganS.(2014), "Sustainable Studies on Concrete with GGBS as a Replacement Material in Cement”, Jordan Journal of Civil Engineering, Vol.8, pp. 263-270.

3. Biddah, A (2006), "Structural Reinforcement of Bridge Decks Using Pultruded GFRP Grating”, Journals of Composite Structures, Vol. 74, pp. 80-88.

4. Cheng, Ran Huang, Jiann-Kuo Wu, Cheng-Hsin Chen (2005), "Influence of GGBS on Durability and Corrosion Behavior of Reinforced Concrete", Journal of Materials Chemistry and Physics, Vol.93, pp. 404-411.

5. Cree A,N, E.U.Chowdhury A, M.F.Green A, L.A.Bisby B, N.Benicho(2012), "Performance in Fire of FRP-Strengthened and Insulated Reinforced Concrete Columns", Fire Safety Journal, Vol.54, pp.86-95.

6. Dhevaseenaa.P.R, Suguna.K, Raghunath.P.N (2015), "Regression Model for Predicting Study Parameter of GFRP Strengthened Corrosion Damaged RC Column" International Journal of Engineering Science and Technology, vol.4, pp.223-230.

7. Dhevaseenaa.P.R, Suguna.K, Raghunath.P.N (2015), "Strength and Ductility of GFRP Strengthened Corrosion Damaged RC Columns" Asian journal of Engineering and Technology, Vol.3, pp. 101-110.

8. Hany, Zadeh and Antonio, Nnni(2012), "Design Of RC Columns Using Glass FRP Reinforcement", Journal of Composites for Construction, Vol.12, pp.1-42.

9. Harichandran .s and Imad baiyasi(2000), "Repair of Corrosion Damaged Columns Using GFRP Sheets" International Journal of Engineering Science and Technology(IJESIT), vol.6, pp.233-243.

10. Hesham M.diab(2013), "Performance of Different Type of FRP Sheets Bonded to Concrete Using Flexible Adhesive", The Online Journal of Science and Technology(TOJSAT), Vol.3, pp. 116-126.

11. Kaya, M. Dawood , B. Gencturk (2015), "Repair of Corroded and Buckled Short Steel Columns Using Concrete-Filled GFRP Jackets" Journal of Construction and Building Materials, Vol.94, pp.20-27. 
12. Mohamed S. Sayed, Hossam Z. El-Karmouty, Ghada D. Abd-Elhamid(2013), "Structural Performance of Circular Columns Confined by Recycled GFRP Stirrups" Journal of Cement \& Concrete Composites, Vol.29, pp.39-48.

13. Mohd. Shariq A, Jagdish Prasad B, H. Abbas (2013), "Effect of BACILLUS BACTERIA on Age Dependent Static Modulus of Elasticity of Concrete", Journals of Construction and Building Materials, Vol. 41, pp 411-418.

14. Muhammad N.S. Hadi, Weiqiang Wang, M. Neaz Sheikh (2015), “Axial Compressive Behavior of GFRP Tube Reinforced Concrete Columns" Journal of Construction and Building Materials, Vol.81, pp.198-207.

15. Olivia K., J. Bilcik (2008), "Strengthening of Concrete Columns with CFRP", Journals of Composite Structures, Vol.11. pp. 1-9.

16. Panesar D.K., S.E. Chidiac(2007), "Multi-Variable Statistical Analysis for Scaling Resistance of Concrete Containing BACILLUS BACTERIA", Journal of Cement \& Concrete Composites, Vol.29, pp.39-48.

17. Pantazopulou S.J, J.F Bonacci, Sheikh.s, "Repair of Corrosion Damaged Columns with FRP Wraps", Journal of Composite for Construction, Vol.5, pp. 20544-20555.

18. Rahul Ravala, UrmilDave(2013),, "Behavior of GFRP Wrapped RC Columns of Different Shapes", Journal of Cement \& Concrete Composites, Vol.51, pp. 240 - 249.

19. Seung,L, Tadatsugu K, Takafumi, Fuminori T (2003), "An Experimental Study on the Retrofitting Effects of Reinforced Concrete Columns Damaged by Rebar Corrosion Strengthened with Carbon Fiber Sheets", Cement and Concrete Research, Vol.33, pp.563570 .

20. Shariq M., Prasad J. and A.K. Ahuja (2008), "Strength Development of Cement Mortar and Concrete Incorporating BACILLUS BACTERIA", Asian Journal of Civil Engineering (Building And Housing), Vol. 9, pp. 61-74.

21. Sonali Gadpalliwar1, R. Deotale S., Abhijeet R. Narde (2014), "To Study the Partial Replacement of Cement by GGBS \& RHA and Natural Sand by Quarry Sand in Concrete", Journal of Mechanical and Civil Engineering, Volume 11, Issue 2, pp-69-77.

22. Vinayak Awasare, M. V. Nagendra(2014) “Analysis of Strength Characteristics of GGBS Concrete" International Journal of Advanced Engineering Technology, Vol.1, pp.82-84.

23. Wang H.Y. (2008), "The Effects of Elevated Temperature on Cement Paste Containing BACILLUS BACTERIA", Journals of Cement \& Concrete Composites, Vol. 30, pp. 992-999.

24. Yogendra O. Patil,Prof.P.N.PatilDr. Arun Kumar Dwivedi(2013), "GGBS as Partial Replacement of OPC in Cement Concrete - An Experimental Study", International Journal of Scientific Research, Vol. 2, pp. 189-191.

25. Yu A T., Zhang B, Y.B.Cao B, J.G.Teng, "Behavior of Hybrid FRP-Concrete-Steel DoubleSkin Tubular Columns Subjected to Cyclic Axial Compression", Journals of Thin-Walled Structures, Vol.61, pp.196-203. 